\title{
MIOCENE LARGE MAMMALS OF LOUISIANA
}

SCHIEBOUT, Judith A., LSU Museum of Natural Science and Department of Geology \& Geophysics, Louisiana State University, Baton Rouge, LA 70803 and YANN, Lindsey T., Anatomy \& Cell Biology, Oklahoma State University Center for Health Sciences, 1111 W 17th Street, Tulsa, OK 74107,jschie@1su.edu

Sites on Fort Polk in western Louisiana were the only source of Miocene terrestrial vertebrates in the state, starting from an initial find of a merychippine horse dentary in 1993, up until an additional discovery in southeastern Louisiana in the Pascagoula Formation in June of 2005. There are five main sites or site clusters in the Castor Creek Member of the Fleming Formation on Fort Polk in west central Louisiana and one site in the Pascagoula Formation, the Tunica Hills/Kerry site in the Tunica Hills north of Baton Rouge.

The Castor Creek Member was originally defined as marine but the Miocene-mammal-bearing sites in the upper third are mainly terrestrial with both small and large vertebrate finds associated with concentrations of soilformed nodules. A stratigraphically low site has yielded both terrestrial mammals and a mysticete whale petrosal. The Fort Polk Miocene faunas are early Late Barstovian, after the middle Miocene climatic optimum, in a period marked by marine regression. Specimens of Carnivora (Cynarctus, Bassariscus, Miomustela) Artiodactyla (Dyseohyus, cf. Merychyus, ?Aepycamelus, cf. Pseudoparablastomeryx, Prosynthetoceras francisi), Perissodactyla (Merychippus, Cormohipparion, Aphelops), and Proboscidea (Gomphotherium) have been recovered, mainly through surface search and quarrying, although a few have been recovered in screening. Removal of heavy encrustation just revealed a new merychippine dentary, the most complete horse specimen yet from Fort Polk. The Fort Polk Miocene sites are considered to fall within a range in age from 13.5 to $14 \mathrm{Ma}$ and be correlative to the Cold Spring Local Fauna of east Texas.

The Pascagoula Formation in Louisiana is exposed in Tunica Hills creeks, and the blue-green, clayey silt at the fossil site is considered an estuary deposit. The largest mammal finds include a mastodon (Mamut $\mathrm{cf}$. $M$. matthewi) palate with teeth and associated tusks, and an associated humerus, femur, pelvis, ribs, and part of the tail of the short-legged rhinoceros 
Teleoceras. Both probably came to the site via bloat-and-float. Other large mammals include horses (Cormohipparion, Neohipparion, Nannipus), a dwarf rhino, a lamine camelid, a six-horned antilocaprid, a juvenile cervid, and a borophagine canid. Site age is Hemphillian. 